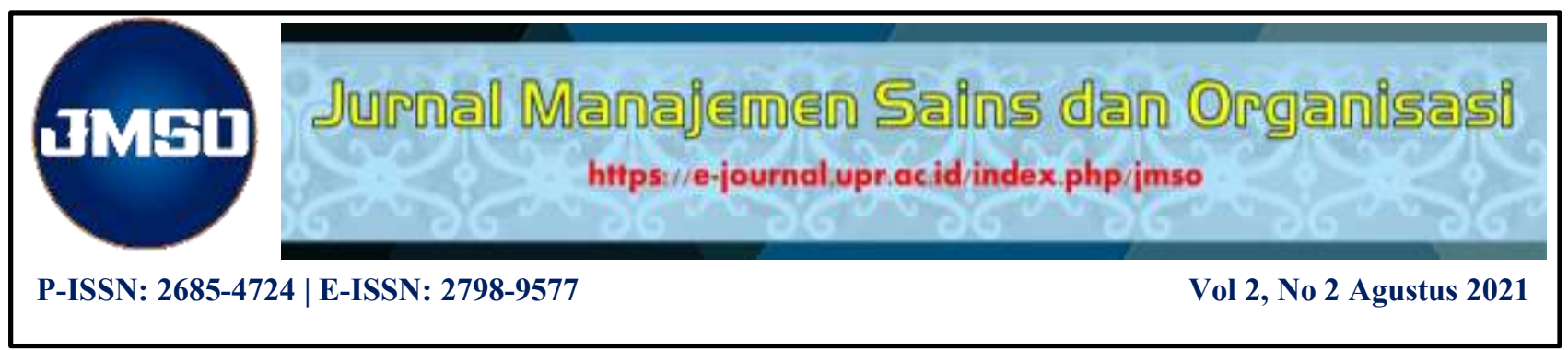

\title{
Analisis kinerja keuangan menggunakan metode EVA dan MVA pada perusahaan semen yang terdaftar di BEI
}

\author{
Citra Dewi Wulantika Manda Sari \\ Fakultas Ekonomi dan Bisnis Universitas Palangka Raya, Indonesia
}

\begin{abstract}
Abstrak
Tujuan, - Tujuan penelitian ini adalah untuk mengetahui kinerja keuangan perusahaan yang terdaftar di Bursa Efek Indonesia (BEI) selama tahun penelitian 2015 sampai dengan tahun 2020.

Desain/Methodologi/Pendekatan - Metode penelitian yang digunakan adalah pendekatan penelitian deskriptif-kuantitatif. Teknik analisis data penelitian ini adalah metode EVA dan MVA. Teknik analisis Trend juga digunakan untuk mengetahui perkembangan kinerja keuangan perusahaan.

Temuan penelitian - Nilai EVA pada perusahaan PT. Indocement Tunggal Prakarsa Tbk, PT. Semen Indonesia (persero) Tbk, dan PT. Semen Baturaja (persero) Tbk bernilai positif (EVA $>0$ ) disetiap tahun penelitian yang berarti perusahaan mampu menciptakan nilai tambah ekonomi bagi perusahaan. Sementara kinerja keuangan menggunakan metode MVA, umumnya masing-masing perusahaan memberikan kekayaan yang substansial bagi pemegang saham. Hal ini ditunjukan dengan nilai MVA yang positif.
\end{abstract}

Kata kunci: Kinerja Keuangan, Perusahaan Semen, Economic Value Added (EVA) dan Market Value Added (MVA)

Jenis artikel: Artikel penelitian

\section{Financial performance analysis using EVA and MVA methods in cement companies listed on the IDX}

\begin{abstract}
Purpose, - The purpose of this study was to determine the financial performance of companies listed on the Indonesia Stock Exchange (IDX) during the research year 2015 to 2020.

Design/methodology/approach - The research method used in this research is descriptivequantitative research approach. The data analysis technique of this research is the EVA and MVA methods. Trend analysis techniques are also used to determine the development of the company's financial performance

Findings - EVA value at the company PT. Indocement Tunggal Prakarsa Tbk, PT. Semen Indonesia (Persero) Tbk, and PT. Semen Baturaja (Persero) Tbk has a positive value (EVA $>0$ ) every year of research, which means the company is able to create economic added value for the company. While financial performance using the MVA method, generally each company provides substantial wealth for shareholders. This is indicated by a positive MVA value.
\end{abstract}




\section{Pendahuluan}

Menurut Kasmir (2016:106) bahwa untuk mengukur kinerja keuangan suatu perusahaan dengan m enggunakan rasio-rasio keuangan, dapat dilakukan dengan beberapa rasio keuangan, setiap rasio keuangan memiliki tujuan, kegunaan, dan arti tertentu. Namun hasil penelitian terdahulu yang dilakukan oleh Judo Triatmojo (2011) menyatakan bahwa dalam pengukuran dengan menggunakan analisis rasio keuangan memiliki kelemahan yaitu tidak memperhatikan biaya modal dalam perhitungannya sehingga sulit untuk mengetahui apakah suatu perusahaan itu telah menciptakan nilai atau tidak. Didorong oleh adanya ketidakpuasan atas lemahnya metode penilaian yang ada dan juga kelemahan-kelemahan lain yang disebabkan oleh mitos pasar serta ukuran-ukuran akuntansi yang seringkali menyesatkan, maka lembaga konsultan manajemen asal dari Amerika serikat, Stern Steward Management Services pada pertengahan 1990-an, mencetuskan konsep yang disebut Economic Value Added (EVA).

Menurut Young \& O'byrne (2001:18) EVA merupakan alat komunikasi yang efektif, baik untuk penciptaan nilai yang dapat dijangkau oleh manajer lini yang akhirnya mendorong kinerja perusahaan dan untuk berhubungan dengan pasar modal. Selain EVA ada pendekatan lain yang dapat digunakan guna mengukur kinerja perusahaan yang didasarkan pada nilai pasar. MVA adalah perbedaan antara nilai pasar ekuitas suatu perusahaan dengan nilai buku seperti yang disajikan dalam neraca, nilai pasar dihitung dengan mengalikan harga saham dengan jumlah saham yang beredar (Brigham \& Houston (2010:50).

MVA merupakan Market Value Added yang dihasilkan kinerja manajerial sepanjang umur perusahaan yang di present valuekan (Young dan O'Bryne, 2001). Selain itu hubungan EVA dan MVA sifatnya tidak selalu searah. Sehingga perusahaan dengan EVA negatif dapat saja memiliki MVA positif jika investor memiliki harapan akan perubahan yang lebih baik pada perusahaan di masa depan.

Berdasarkan harga saham perusahaan semen yang terdaftar di BEI tahun 2015-2020, saham perusahaan semen mengalami penyusutan dan kenaikan, begitu juga dengan masalah oversupply (kelebihan pasokan) yang terjadi karena banyaknya perusahaan semen global yang mencoba masuk ke pasar Indonesia. Oversupply yang berlebihan juga meyebabkan terjadinya perang harga, yang dikhawatirkan investor bisa mempengaruhi profitabilitas emiten tersebut dan mempengaruhi investor melepas kepemilikan saham-saham semennya. Beberapa masalah diatas tentunya akan mempengaruhi kinerja perusahaan terutama kinerja keuangan. Untuk melihat seberapa besar pengaruhnya terhadap kinerja keuangan perusahaan, maka perlu dilakukan evaluasi kinerja keuangan perusahaan.

\section{Kajian Pustaka}

Berdasarkan tinjauan pustaka yaitu kajian teori, penelitian terdahulu, dan juga tujuan penelitian maka disusunlah sebuah kerangka konseptual sebagai sebuah model penelitian untuk menjelaskan bagaimana kinerja keuangan perusahaan semen yang terdaftar di BEI, yaitu: 


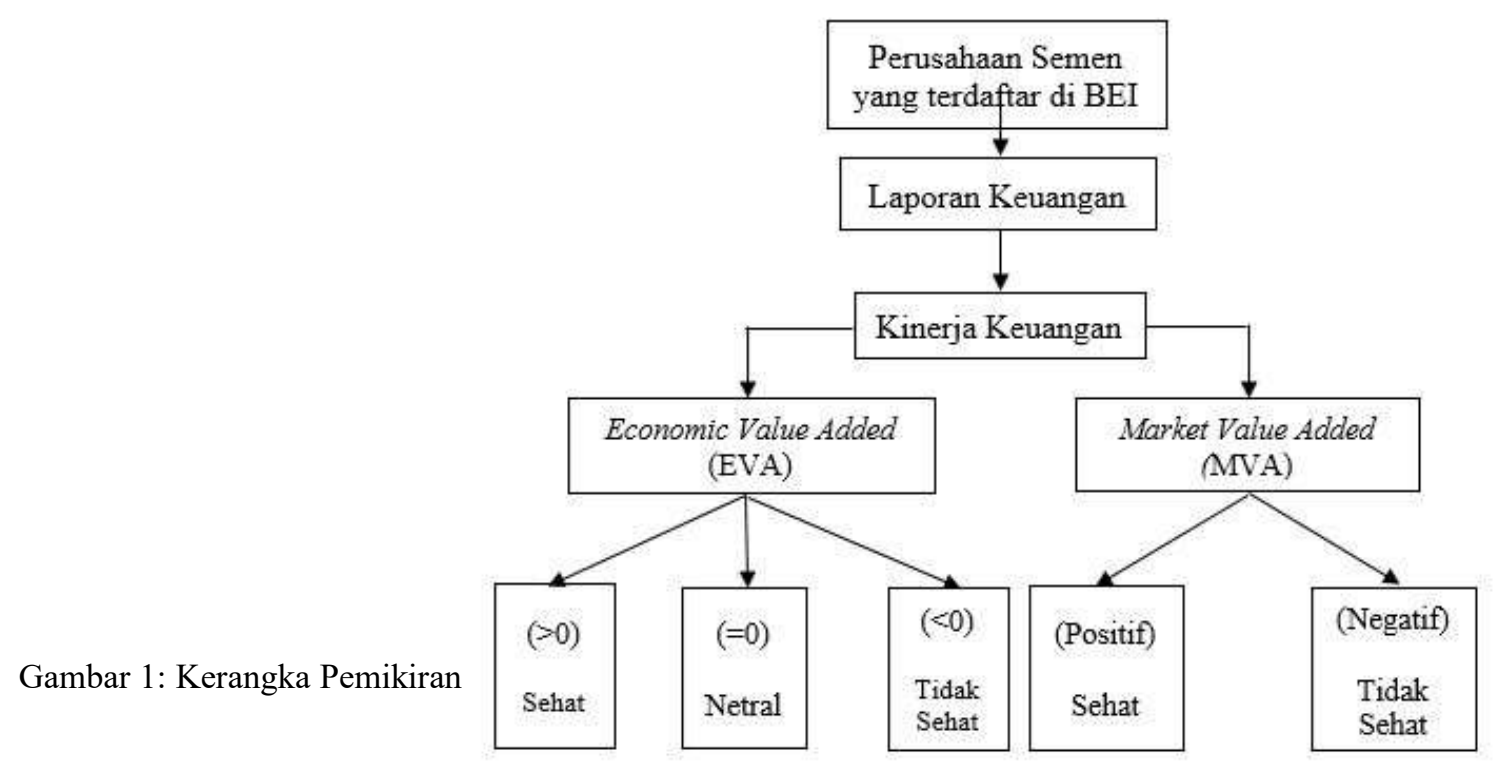

\section{Kinerja keuangan:}

Irham Fahmi (2015) kinerja keuangan adalah suatu analisis yang dilakukan untuk melihat sejauh mana suatu perusahaan telah melaksanakan dengan menggunakan aturan-aturan pelaksanaan keuangan secara baik dan benar. Seperti dengan membuat suatu laporan keuangan yang telah memenuhi standar dan ketentuan dalam SAK (Standar Akuntansi Keuangan) atau GAAP (General Accepted Acounting Principle), dan lainnya.

\section{EVA (Economic Value Added):}

Young \& O'byrne (2001:18) EVA merupakan alat komunikasi yang efektif, baik untuk penciptaan nilai yang dapat dijangkau oleh manajer lini yang akhirnya mendorong kinerja perusahaan dan untuk berhubungan dengan pasar modal. (Young \& O’byrne, 2001:18)

NOPAT (Net Operating After Tax) adalah laba operasi perusahaan setelah pajak dan mengukur laba yang diperoleh perusahaan dari operasi yang berjalan. (Annisa Tamba:2012) Invested Capital adalah jumlah seluruh pinjaman perusahaan diluar pinjaman jangka pendek tanpa bunga, seperti utang dagang, biaya yang masih harus dibayar, utang pajak, dan uang muka pelanggan. (Annisa Tamba:2012)

WACC (Weighted Average Cost of Capital) merupakan rata-rata tertimbang biaya utang dan modal sendiri menggambarkan tingkat pengembalian investasi minimum untuk mendapatkan tingkat pengembalian yang diharapkan oleh investor. (Mamduh M. Hanafi, 2016:275)

Capital Charges atau biaya modal adalah biaya riil yang harus dikeluarkan oleh perusahaan untuk memperoleh dana baik yang berasal dari hutang, saham preferen, saham biasa, maupun laba ditahan untuk mendanani suatu investasi atau operasi perusahaan. (Rudianto 2006:342)

\section{MVA (Market Value Added):}

Young dan O'Bryne (2001) MVA adalah nilai yang diperoleh pemegang saham, atau dengan kata lain Market Value Added adalah kekayaan yang dapat diciptakan perusahaan untuk pemegang saham.

\section{Hipotesis}

Kinerja keuangan dengan metode Economic Value Added (EVA) dalam kategori sehat pada perusahaan semen yang terdaftar di Bursa Efek Indonesia (BEI) dan kinerja keuangan dengan 
metode Market Value Added (MVA) dalam kategori sehat pada perusahaan semen yang terdaftar di Bursa Efek Indonesia (BEI).

\section{Metode Penelitian}

Dalam penelitian ini jenis pendekatan yang digunakan adalah pendekatan kuantatif yang berbentuk angka dan data. Menurut Sugiyono (2017:8) penelitian kuantitatif adalah Metode penelitian yang berlandaskan pada filsafat positivisme, digunakan untuk meneliti pada populasi atau sampel tertentu, pengumpulan data menggunakan instrument penelitian, analisis data bersifat kuantutatif atau statistik, dengan tujuan untuk menguji hipotesis yang telah ditetapkan.

Sumber data yang digunakan dalam penelitian ini adalah data sekunder yaitu berupa laporan keuangan yang diperoleh dari publikasi tahunan dari situs resmi Bursa Efek Indonesia yakni www.idx.co.id beserta literatur yang berkaitan dengan penelitian kemudian data diolah dan dianalisis.

Populasi dalam penelitian ini adalah seluruh perusahaan semen yang terdaftar di BEI yang berjumlah 6 perusahaan, dan sampel dalam penelitian ini adalah 3 perusahaan yaitu PT. Indocement Tunggal Prakarsa Tbk, PT. Semen Indonesia (persero) Tbk, dan Semen Baturaja (persero) Tbk yang telah dipilih berdasarkan kriteria dengan menggunakan teknik puposive sampling.

Teknik analisis data dalam penelitian ini yaitu menggunakan metode EVA dan MVA. Selain dengan pendekatan EVA dan MVA, teknik analisis Trend juga digunakan untuk mengetahui perkembangan kinerja keuangan perusahaan. Adapun langkah-langkah dalam EVA menurut Maheni dan Bayu (2018) adalah sebagai berikut:

\section{Menghitung Net Operating After Tax (NOPAT)}

NOPAT $=$ Laba Bersih After Tax + Biaya Bunga

Mengitung Modal Investasi (invested capital)

Invested capital $=$ Total Liabilitas dan Ekuitas - Hutang jangka pendek

Menghitung Weight Average of Capital (WACC)

$\mathrm{WACC}=\mathrm{D} \times \mathrm{rd}(1-\mathrm{T})+\mathrm{E} \times \mathrm{re}$

Tingkat modal hutang (the level of debt capital)

Total Hutang $(D)=\frac{\text { Total Hutang }}{\text { Total Hutang dan Ekuitas }} \times 100 \%$

Biaya hutang (cost of debd /rd )

Biaya Hutang $(\mathrm{rd})=\frac{\text { Biaya Bunga }}{\text { Total Hutang }} \times 100 \%$

Tingkat modal ekuitas (the level of equity capital)

Total Ekuitas $(\mathrm{E})=\frac{\text { Total Ekuitas }}{\text { Total utang dan Ekuitas }} \times 100 \%$

Biaya ekuitas (cost of equity)

Biaya Bunga Ekuitas (re) $=\frac{\text { Laba Bersih Setelah Pajak }}{\text { Total Ekuitas }} \times 100 \%$

Menghitung tingkat pajak (Tax Rate)

Berdasarkan Pasal 17 ayat (1) bagian b UU No. 36 Tahun 2008 tentang Pajak Penghasilan, tarif pajak yang dikenakan kepada badan adalah 25\%. Besar tarif ini berlaku sampai tahun 
pajak 2019. Jadi tingkat pajak/tarif pajak yang digunakan dalam penelitian ini adalah $25 \%$ untuk PT. Indocement Tunggal Prakarsa Tbk, PT. Semen Indonesia (persero) Tbk, dan Semen Baturaja (persero) Tbk. Dalam Pasal 5 Perppu No. 1/2020 dijelaskan Penyesuaian tarif Pajak Penghasilan Wajib Pajak badan dalam negeri dan bentuk usaha tetap berupa penurunan tarif Pasal 17 ayat (1) huruf b Undang-Undang mengenai Pajak Penghasilan menjadi sebesar 22\% (dua puluh dua persen) yang berlaku pada Tahun Pajak 2020.

\section{Menghitung Capital Chargers atau Biaya Modal}

Capital Chargers $=$ Invested Capital $\mathrm{x}$ WACC

Menghitung EVA

EVA $=$ NOPAT - Capital Chargers

Pada EVA dapat dikelompokkan ke dalam 3 kategori yang berbeda, yaitu:

Nilai EVA $>0$ atau EVA bernilai positif

Pada posisi ini berarti manajemen perusahaan telah berhasil menciptakan nilai tambah ekonomis bagi perusahaan.

Nilai EVA $=0$

Pada posisi ini berarti manajemen perusahaan berada dalam titik impas. Perusahaan tidak mengalami kemunduran tetapi sekaligus tidak mengalami kemajuan secara ekonomi.

Nilai EVA $<0$ atau EVA bernilai negatif

Pada posisi ini berarti tidak terjadi proses penambahan nilai ekonomis bagi perusahaan, dalam arti laba yang dihasilkan tidak dapat memenuhi harapan para kreditor dan pemegang saham perusahaan (investor).

Sedangkan langkah-langkah MVA menurut Mahenika dan Bayu (2018) adalah sebagai berikut:

MVA $=$ Nilai pasar saham - ekuitas yang diberikan pemegang saham

$$
=(\text { saham yang beredar })-\text { (harga saham }) \text { - total ekuitas saham biasa. }
$$

Jika nilai MVA positif menunjukkan perusahaan telah menciptakan kekayaan yang substansial bagi pemegang saham. Tetapi, jika nilai MVA yang negatif berarti nilai dari investasi yang dijalankan manajemen kurang dari modal yang diserahkan kepada perusahaan oleh pasar modal yakni kekayaan telah dimusnahkan. (Young dan O’Byrne: 2001: 27)

Teknik Analisis Trend

Analisis trend digunakan untuk mengetahui perkembangan kinerja keuangan PT Indocement Tunggal Prakarsa Tbk, PT Semen Indonesia (Persero) Tbk, dan PT Semen Baturaja Tbk periode tahun 2015-2020. Berdasarkan trend angka-angka hasil dari nilai EVA dan MVA tertentu dapat diperoleh gambaran mengenai naik, turun, atau konstan rasio-rasio tersebut. Menurut Kasmir (2016) analisis trend merupakan analisis laporan keuangan yang biasanya dinyatakan dalam persentase tertentu.

\section{Hasil Dan Pembahasan}

Analisis Economic Value Added (EVA)

Untuk menghitung nilai Economic Value Added (EVA) dapat digunakan rumus sebagai berikut:

$$
\boldsymbol{E} \boldsymbol{V} \boldsymbol{A}=(\mathrm{NOPAT})-\text { Capital Charges }(\mathrm{CC})
$$


Tabel 2.

Rekapitulasi perhitungan nilai EVA (dalam jutaan rupiah)

\begin{tabular}{|c|c|c|c|c|}
\hline Tahun & $\begin{array}{c}\text { NOPAT } \\
\text { (1) }\end{array}$ & $\begin{array}{l}\mathrm{CC} \\
(2)\end{array}$ & $\begin{array}{l}\text { EVA } \\
(1-2)\end{array}$ & $\begin{array}{c}\text { Peningkatan/ } \\
\text { penurunan } \\
(\%)\end{array}$ \\
\hline \multicolumn{5}{|c|}{ INTP } \\
\hline 2015 & Rp.4.383.204 & Rp.3.949.683 & Rp.433.521 & - \\
\hline 2016 & Rp.3.882.142 & Rp.3.470.117 & Rp.412.025 & $-5 \%$ \\
\hline 2017 & Rp.1.873.911 & Rp.1.644.925 & Rp.228.986 & $-44 \%$ \\
\hline 2018 & Rp.1.164.598 & Rp.995.083 & Rp.169.515 & $-26 \%$ \\
\hline 2019 & Rp.1.843.043 & Rp.1.585.097 & Rp.257.946 & $52 \%$ \\
\hline 2020 & Rp.1.857.438 & Rp.1.540.372 & Rp.317.066 & $23 \%$ \\
\hline \multicolumn{3}{|c|}{ Rata-rata } & Rp.303.177 & \\
\hline \multicolumn{5}{|c|}{ SMGR } \\
\hline 2015 & Rp.4.895.445 & Rp.3.972.640 & Rp.922.805 & - \\
\hline 2016 & Rp.4.898.530 & Rp.3.921.377 & Rp.977.152 & $6 \%$ \\
\hline 2017 & Rp.846.272 & Rp.674.687 & Rp.171.585 & $-0,82 \%$ \\
\hline 2018 & Rp.640.186 & Rp.480.714 & Rp.159.472 & $-7 \%$ \\
\hline 2019 & Rp.5.576.531 & Rp.4.025.802 & Rp.1.550.729 & $872 \%$ \\
\hline 2020 & Rp.4.995.124 & Rp.3.805.468 & Rp.1.189.656 & $-23 \%$ \\
\hline \multicolumn{3}{|c|}{ Rata-rata } & Rp.828.567 & \\
\hline \multicolumn{5}{|c|}{ SMBR } \\
\hline 2015 & Rp.354.330 & Rp.328.883 & Rp.25.447 & - \\
\hline 2016 & Rp.266.209 & Rp.246.637 & Rp.19.571 & $-0,23 \%$ \\
\hline 2017 & Rp.147.394 & Rp.127.793 & Rp.19.600 & $0,1 \%$ \\
\hline 2018 & Rp.194.722 & Rp.146.070 & Rp.48.651 & $148 \%$ \\
\hline 2019 & Rp.187.682 & Rp.135.733 & Rp.51.949 & $7 \%$ \\
\hline 2020 & Rp.194.760 & Rp.131.461 & Rp.63.299 & $22 \%$ \\
\hline
\end{tabular}

Sumber: Pengolahan data dari lampiran

Berikut ini grafik perbandingan dari masing-masing perusahaan semen:

Gambar 1. Grafik

Rata-rata Hasil EVA

\section{Nilai Rata-rata hasil EVA Tahun 2015-2020 \\ (dalam jutaan rupiah)}

Rp900,000

Rp800,000

Rp700,000

Rp600,000

$\mathrm{Rp} 500,000$

Rp400,000

Rp300,000

Rp200,000

Rp100,000

$\mathrm{Rp}-$

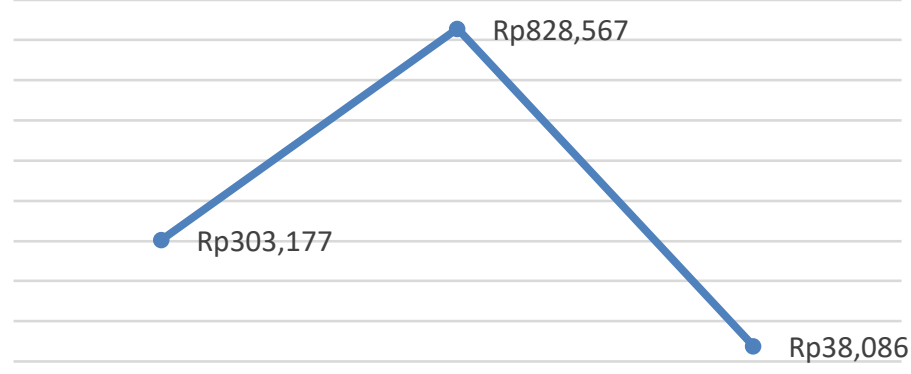

PT. Indocement PT. Semen Indonesia PT. Semen Baturaja Tunggal Prakarsa Tbk (persero) Tbk $\quad$ (persero) Tbk

Sumber: Pengolahan data dari tabel 2

Berdasarkan rekapitulasi dari EVA pada grafik diatas, PT. Semen Indonesia (persero) Tbk merupakan penghasil nilai terbesar nilai tambah rata-rata sebesar Rp.828.567. Sedangkan PT. Indocement Tunggal Prakarsa Tbk menghasilkan nilai rata-rata per perusahaan sebesar Rp. 
303.177 dan PT Semen Baturaja (persero) sebesar Rp. 38.086. Nilai EVA pada perusahaan semen periode 2015-2020 mengalami hasil yang baik walaupun terjadi hasil yang fluktuatif pada tahun-tahun penelitian. Dengan demikian para manajer telah mampu memberikan hasil yang positif terhadap penyandang dana perusahaan.

Analisis Market Value Added (MVA)

Untuk menghitung nilai Market Value Added (MVA) dapat digunakan rumus sebagai berikut:

$\boldsymbol{M V A}=($ Jumlah Saham yang Beredar) (Harga saham) - Total ekuitas Saham Biasa

Tabel 3. Rekapitulasi Perhitungan Market Value Added (MVA) (dalam jutaan rupiah)

\begin{tabular}{|c|c|c|}
\hline Tahun & MVA & $\begin{array}{c}\text { Peningkatan/ } \\
\text { penurunan } \\
(\%)\end{array}$ \\
\hline \multicolumn{3}{|c|}{ INTP } \\
\hline 2015 & Rp.82.183.471.541.472 & - \\
\hline 2016 & Rp.56.690.944.298.650 & $-31 \%$ \\
\hline 2017 & Rp.80.803.011.236.543 & $43 \%$ \\
\hline 2018 & Rp.70.771.651.624.713 & $-12 \%$ \\
\hline 2019 & Rp.70.035.409.993.214 & $-1 \%$ \\
\hline 2020 & Rp.53.285.806.666.777 & $-24 \%$ \\
\hline Rata-rata & Rp.68.961.715.893.562 & \\
\hline \multicolumn{3}{|c|}{ SMGR } \\
\hline 2015 & Rp.67.591.887.202 & - \\
\hline 2016 & Rp.54.391.121.609 & $-20 \%$ \\
\hline 2017 & Rp.58.691.608.948 & $8 \%$ \\
\hline 2018 & Rp.68.181.594.346 & $16 \%$ \\
\hline 2019 & Rp.71.144.336.076 & $4 \%$ \\
\hline 2020 & Rp.73.663.470.240 & $4 \%$ \\
\hline Rata-rata & Rp.65.610.669.737 & \\
\hline \multicolumn{3}{|c|}{ SMBR } \\
\hline 2015 & Rp.2.859.814.946 & - \\
\hline 2016 & Rp.27.444.000.863 & $860 \%$ \\
\hline 2017 & Rp.37.710.815.741 & $37 \%$ \\
\hline 2018 & Rp.17.378.460.829 & $-54 \%$ \\
\hline 2019 & Rp.10.574.666.417 & $-39 \%$ \\
\hline 2020 & Rp.4.366.907.072 & $-59 \%$ \\
\hline Rata-rata & Rp.16.722.444.311 & \\
\hline
\end{tabular}

Sumber: Pengolahan data dari lampiran

\section{Nilai Rata-rata hasil MVA Tahun 2015-2020}

$\operatorname{Rp} 80,000,000,000,000$

Gambar 2. Grafik Rata-rata Hasil MVA Rp60,000,000,000,000 Rp40,000,000,000,000 Rp20,000,000,000,000

$\mathrm{Rp}-$

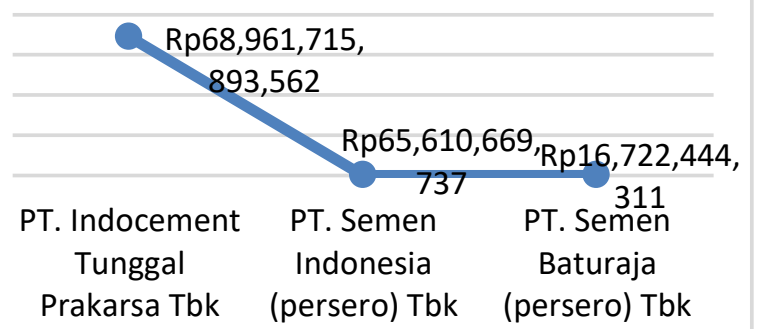

Sumber: Pengolahan data dari tabel 3 
Berdasarkan rekapitulasi dari MVA pada grafik diatas, PT. Indocement Tunggal Prakarsa Tbk merupak`an penghasil nilai MVA rata-rata terbesar yaitu Rp.68.961.715.893.562. PT. Semen Indonesia (persero) Tbk menghasilkan nilai rata-rata per perusahaan sebesar Rp. 65.610.669.737 dan PT Semen Baturaja (persero) sebesar Rp. 16.722.444.311 Terlihat juga bahwa ketiga perusahaan memiliki nilai rata-rata MVA yang positif walaupun terjadi hasil yang fluktuatif pada tahun-tahun penelitian. Selama periode 2015-2020 semua perusahaan mampu memberikan kesejahteraan bagi para pemegang saham.

\section{Kesimpulan Dan Saran}

Analisis kinerja keuangan dengan menggunakan metode Economic Value Added (EVA) Pada PT. Indocement Tunggal Prakarsa Tbk, PT. Semen Indonesia (persero) Tbk, dan PT. Semen Baturaja (persero) Tbk pada tahun 2015-2020 mengalami nilai EVA yang selalu positif $(E V A>0)$ disetiap tahun penelitian, walaupun kinerja keuangan yang dihasilkan mengalami jumlah nilai EVA yang naik-turun (fluktuatif). Hal ini menunjukkan bahwa perusahaan mampu menciptakan nilai tambah ekonomis baik bagi perusahaan maupun bagi pemilik saham berupa tambahan kekayaan, karena tingkat biaya modal lebih rendah dibandingkan tingkat pengembalian laba operasi perusahaan.

Sementara nilai pasar saham pada PT. Indocement Tunggal Prakarsa Tbk, PT. Semen Indonesia (persero) Tbk, dan PT. Semen Baturaja (persero) Tbk umumnya masing-masing perusahaan mampu memberikan kesejahteraan bagi para pemegang saham. Nilai pasar saham selalu berada di atas nilai buku. Kapitalisasi pasar atau nilai pasar ekuitas selalu lebih tinggi dari total nilai ekuitas. Meskipun hasil yang diperoleh tidak stabil/fluktuatif, dimulai dengan nilai yang tinggi kemudian mengalami penurunan, kenaikkan, dan mengalami penurunan kembali tetapi nilai MVA masih selalu positif.

\section{Saran}

Bagi manajemen perusahaan, harus mampu mengevaluasi kinerja keuangan perusahaan untuk meningkatkan nilai Economic Value Added (EVA) maka perusahaan perlu untuk menekan cost of capital untuk meningkatkan laba perusahaan. Dengan meningkatnya nilai EVA akan memberikan imbal balik yang baik bagi perusahan dan juga pemegang saham.

Bagi perusahaan agar nilai MVA lebih stabil harus mampu meningkatkan laba sehingga para investor dan kreditor lebih tertarik untuk menanamkan saham di perusahaan, harga saham pun stabil dan cenderung mengalami kenaikan. Bagi investor dan calon investor, penelitian kinerja perusahaan tidak hanya dilihat dari satu sisi internal saja, akan tetapi juga dilihat dari sisi eksternal agar dapat memperkirakan prospek perusahaan di masa mendatang.

\section{Daftar Pustaka}

Arikunto, S. (2013). Prosedur Penelitian Suatu Pendekatan Praktik. Jakarta: Rineka Cipta. Anggoro Dwi Putra, Economic Value Added (EVA) dan Market Value Added (MVA) Sebagai Alat Ukur Kinerja Keuangan (Studi Pada PT. HM Sampoerna, Tbk dan PT. Gudang Garam, Tbk Periode 2011-2013), Jurnal Manajemen

Anesti Iswandira, Immas Nurhayati, dan Titing, Analisis Economic Value Added (EVA) dan Market Value Added (MVA) Sebagai Alat Untuk Mengukur Kinerja Keuangan Perusahaan PT. Indofood Sukses Makmur Tbk, Jurnal Ilmiah Inovator, Edisi Maret 2015. 
Annisa T. 2012. Analisis Kinerja Keuangan Dengan Menggunakan Pendekatan EVA (Economic Value Added) dan MVA (Market Value Added) pada Bank BUMN yang go public. Makasar. Skripsi Universitas Hasanuddin.

Baridwan, Zaky \& Legowo, Ary. 2002. Asosiasi Antara EVA (Economic Value Added), MVA (Market Value Added) dan Rasio Profitabilitas Terhadap Harga Saham. Tema, Vol III. September

Bambang Wahyudiono, 2014. Laporan Keuangan, Jakarta: Penerbit Raih Asa Sukses

Brigham, Eugene F. Dan J.F. Houston. 2010. Dasar-Dasar Manajemen Keuangan. Edisi 11 Buku 1. Jakarta: Salemba Empat.

Brigham, Eugene F. Dan J.F. Houston. 2013. Dasar-Dasar Manajemen Keuangan. Edisi 11 Buku 2 Jakarta: Salemba Empat.

Fahmi, Irham. 2015. Analisis Laporan Keuangan. Bandung: Alfabeta

Hanafi Mamduh M. Abdul Halim. 2016. Analisis Laporan Keuangan. Yogyakarta: UPP STIM YKPN

Hanafi Mamduh M. 2016. Manajemen Keuangan. Yogyakarta: BPFE Yogyakarta

Indrawan, Rully., Yaniawati, R. Poppy, 2016. Cetakan Kedua. Metodelogi Penelitian, Bandung:PT. REFINIKA ADITAMA

Judo Triadmojo, Model Terbaik Dalam Memprediksi Return: Return On Equity (ROE), Atau Economic Value Added (EVA), Media Riset Akuntansi, Vol 1 No 2 Agustus 2011

Kasmir, 2016. Analisis Laporan Keuangan, Jakarta: PT Raja Grafindo Persada.

Lailatul M. 2018. Analisis Kinerja Keuangan Perusahaan Pertambangan Menggunakan Metode Economic Value Added (EVA) Dan Market Value Added (MVA)Periode 20122017 (Studi Kasus Pada Perusahaan Pertambangan Yang Terdaftar Di Bursa Efek Indonesia). Skripsi Fakultas Ekonomi Universitas Negeri: Yogyakarta.

Munawir, S. 2002. Analisis Laporan Keuangan. Edisi 2. Yogyakarta: Liberty.

Maheni Ika, Bayu Wijayantini, Mengukur Kinerja keuangan Dengan EVA dan MVA. Jurnal Manajemen dan Bisnis ISSN: 1410-4571, E-ISSN: 25412604.

Muslikah, Anita. Pengaruh Economic Value Added dan Market Value Added Terhadap Indeks Harga Saham Individual Pada Perusahaan-Perusahaan Property dan Real Estate Yang Terdaftar Di Bursa Efek Indonesia Periode 2013-2015. Jurnal Manajemen dan Bisnis. Penerbit: Jurusan Manajemen Fakultas Ekonomi dan Bisnis, Universitas Cenderawasih Page Volume1 Nomor 1 Januari 2017.

Oktin, Antonia. 2018. "Pengaruh Economic Value Added (EVA) dan Market Value Added (MVA) Terhadap Harga Saham”. Skripsi. Fakultas Ekonomi Jurusan Akuntansi Universitas Sanata Dharma: Yogyakarta.

Rinda Savitri. Pengukuran Kinerja Keuangan Menggunakan Rasio Keuangan Dan Economic Value Added (EVA) (Studi Kasus Pada Perusahaan PT Telkom Indonesia, Tbk Yang Terdaftar Di Bursa Efek Indonesia Periode 2008-2012). Jurnal Manajemen dan Bisnis

Rudianto. 2006. Akuntansi Manajemen. Jakarta: PT Gramedia

Rudianto. 2013. Akuntansi Manajemen Informasi Untuk Pengambilan Keputusan Strategis. Jakarta: Erlangga

Sugiyono. 2017. Metode Penelitian Kuantitatif, Kualitatif, dan R\&D. Bandung: Alfabeta, CV 
Septiyani, Melinda. 2015. Pengaruh Economic value Added dan Market Value Added Terhadap Nilai Perusahaan Dalam Indeks LQ-5 Periode 2010-2013. Skripsi. Fakultas Ilmu Ekonomi dan Bisnis Universitas Islam Bandung

Young, David S. \& O Byrne, Stephen F. 2001. EVA \& Manajemen Berdasarkan Nilai: Panduan Praktis Untuk Implementasi, Edisi 1, Jakarta: Selemba Empat.

Wahyudiono, Bambang. 2014. Mudah Membaca Laporan keuangan. Jakarta: Raih Asa Sukses (Penebar Swadaya Grup).

https://economy.okezone.com/read/2014/05/13/279/984121/kontribusi-industri-semen-bagipembangunan (Dikutip pada 10 November 2019)

https://www.idx.com (Dikutip pada 10 November 2019)

https://www.eddyelly.com/2019/daftar-daftar-perusahaan-manufaktur-tahun2018.html?m=1 (Dikutip pada 10 November 2019)

corresponding author

e-mail:citrad417.gmail.com 